\title{
Bacterial invasion of dentinal tubules from the external root surface with and without an intact cemental layer- a confocal laser scanning microscopic study
}

\begin{abstract}
Aim: To evaluate the invasion of two bacterial species; Streptococcus sanguinis (S.s) and Aggregatibacter actinomycetemcomitans (A.a) in radicular dentinal tubules with and without an intact cemental layer using confocal laser scanning microscopy.

Methodology: 10 intact freshly extracted human teeth were prepared and divided into 2 groups, Group 1: S.s (1a: S.s without cementum, 1b: S.s with intact cementum) and Group 2:A.a (2a:A.a without cementum, 2b: with intact cementum). The cemental layer on each root was removed from one side and kept intact on the other side. The specimens were incubated in the bacterial suspension for 15 days at $37^{\circ} \mathrm{C}$. The specimens were sectioned, mounted, stained with a fluorescent dye and viewed under the Confocal Scanning Electron Microscope at 40X magnification. The penetration of bacteria and presence of live bacteria in dentinal tubules in all the groups was analyzed.
\end{abstract}

Results: In both the groups there was a significantly higher penetration of bacteria through the exposed dentin as compared to sections with intact cementum. However, there was a significantly higher penetration of Streptococcus sanguinis as compared to Aggregatibacter actinomycetemcomitans.

Conclusion: An intact cemental layer protects the dentin from invasion of bacterial species. These bacteria can lead to reinfection of treated periodontal pockets, pulpal inflammation or persistence of periapical infections. Therefore, management of endodontic-periodontic lesions and periodontal therapies should aim at preserving or regenerating a healthy cemental layer.

Keywords: bacterial invasion, confocal scanning electron microscope, cementum, radicular dentin

\section{Introduction}

Periodontitis is a complex multifactorial inflammatory condition characterized by the destruction of connective tissue and alveolar bone support following an inflammatory host response secondary to infection by periodontal bacteria. ${ }^{1,2}$

Streptococci are the primary bacterial colonizers of the oral cavity, and adhesion of streptococci to the acquired pellicle is an essential first step in colonization of the tooth surfaces. ${ }^{3}$

Periodontopathogenic bacteria are gram-negative, anaerobic or facultative organisms that exhibit various virulent factors. Aggregatibacter actinomycetemcoitans and organisms belonging to the 'red complex' that are $P$. gingivalis, $T$. denticola, $T$. forsythia are secondary colonisers and appear later in biofilm formation. ${ }^{4}$ Aggregatibacter actinomycetemcomitans is generally associated with localized aggressive periodontitis (LAP).

Invasion of dentinal tubules by bacteria from supra or sub gingival plaque occurs whenever dentin is exposed in the oral cavity. This can be through carious lesions, restorative or periodontal procedures, tooth wear, enamel or dentin cracks, or dental trauma. ${ }^{6-9}$

Bacterial invasion of radicular dentin of periodontally diseased teeth
Volume 4 Issue I - 2018

\author{
Jovita D'souza,' Sneha Gokhale, ${ }^{2}$ \\ VikramPadbidri, ${ }^{3}$ Lovely M' \\ 'Department of Periodontics, Ras Al Khaimah College of Dental \\ Sciences, UAE \\ ${ }^{2}$ Bhandal Dental Practice, UK \\ ${ }^{3}$ Department of Microbiology, Jehangir Hospital, India
}

Correspondence: Jovita D'souza, Adjunct Faculty, Department of Periodontics, Ras Al Khaimah College of Dental Sciences, RAK, UAE,Tel +97I567068295, Email dr.jovita@gmail.com

Received: December 10, 2017 | Published: January 23, 2018 has been demonstrated by light microscopic ${ }^{10-12}$ and microbiological studies. ${ }^{13,14}$ It has been suggested that the dentinal tubule microflora associated with a periodontal pocket could act as a reservoir for recolonization of the pocket after debridement. ${ }^{13,14}$

Numerous studies have been done to review bacterial invasion through dentinal tubules from the pulp space ${ }^{15-18}$ but there is less literature on bacterial penetration through cementum.

Cemental matrix is porous and in healthy situation only enables permeability of water and inorganic ions. But in diseased state plaque bacterial invasion has been detected in 10-12micron deep surface layer. ${ }^{19}$

Invasion of radicular dentinal tubules by pure cultures of Streptococcus has been demonstrated in various studies, ${ }^{17}$ but the invasion of gram negative anaerobic bacteria is less clear. While it is known that bacteria are able to invade radicular dentine from the periodontal pocket, a contentious issue whether bacteria invade healthy cementum or gain access to dentinal tubules only from breaches in the cemental layer still exists. The majority of species recovered from radicular dentin are Gram-positive bacteria, with lower numbers of Gram-negative organisms. ${ }^{14}$ The inability to detect fastidious anaerobes within the invading dentin may have been due to difficulties in cultivating these bacteria. 
In this article we evaluated the penetration of two bacterial species, Streptococcus sanguinis and Aggregatibacter actinimycetemcomitans into the dentinal tubules with and without an intact cemental layer using a confocal laser scanning microscopy. A fluorescent dye was used to stain the nucleic acid and differentiate between live and dead bacteria.

\section{Materials and methods}

Ten intact freshly extracted single rooted human teeth were used for the study. Teeth were scaled and planed with the help of ultrasonic scaler. The cemental layer was removed from one surface and kept intact on the other surface. The teeth were decoronated with diamond disc at $700 \mathrm{rpm}$ and dentin blocks of $5 \mathrm{~mm}$ length were prepared. The root canal opening was sealed with gutta-percha and dentinal tubule sealant was applied on all the surfaces except the test surface. EDTA was applied on the rest of the surface with the help of microbrush and the teeth were washed with normal saline after 30seconds. Teeth were then autoclaved in autoclavable pouches to remove any residual bacteria. The teeth were then randomly divided into 2 groups of 5 samples each, Group 1: Streptococcus sanguinis (S.s), Sub group a: S.s without cementum, Sub group b:S.s with intact cementum and Group 2: Aggregatibacter actinomycetemcomitans (A.a) Sub group a:A.a without cementum, Sub group b: with intact cementum.

Separate inoculums of Streptococcus sanguinis and Aggregatibacter actinomycetemcomitans were prepared and adjusted to $0.5 \mathrm{McF}$ arland standards. This ensured uniform concentration of both the bacterial species. Teeth were then incubated in the respective bacterial suspensions for 15 days at $37^{\circ} \mathrm{C}$. After the incubation time the teeth were then washed in normal saline. The teeth were then split longitudinally and sectioned with the help of diamond disc, chisel and mallet. After the sectioning, the samples were again washed with $100 \mu 1$ PBS using a micropipette to remove any debris.

For the examination of tooth specimens under the confocal laser scanning microscope (CLSM) $100 \mu 1$ of prepared fluorescent stain (LIVE/DEAD Baclight stain, Molecular Probes, Invitrogen Detection Technologies) was applied on the sectioned dentin blocks according to manufacturer's instruction and the blocks were incubated with the stain at room temperature for 15 minutes in a dark environment to enable bacteria to take up the stain. After 15 minutes the samples were washed with Phosphate Buffer Solution PBS to remove any residual fluorescent stain. Following this an antifade mountant (Dakocytomation) was applied over the sample and the specimen was then mounted on a slide with glycerine and a cover slip was placed. The samples were then subjected to CLSM imaging at 40X Magnification. The confocal images were analysed and number of live bacteria (Green stained) was estimated (Figure 1-4).

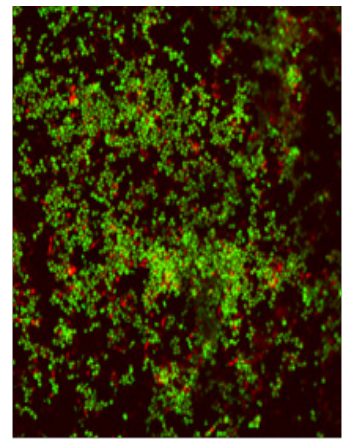

Figure I Group la: Streptococcus sanguinis without intact cemental layer.

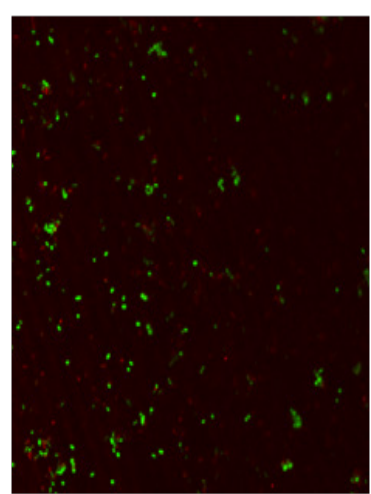

Figure 2 Group Ib: Streptococcus sangunis with intact cemental layer



Figure 3 Group 2a:Aggregatibacter actinomycetemcomitans without intact cemental layer.

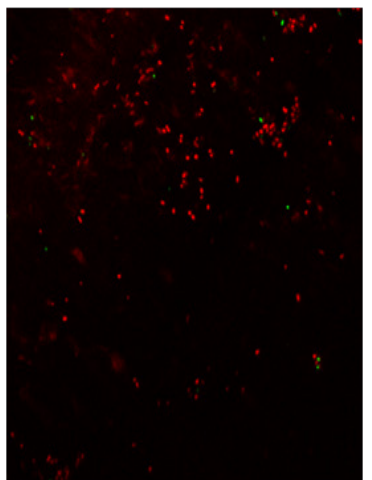

Figure 4 Group 2b:Aggregatibacter actinomycetemcomitans with intact cemental layer.

\section{Statistical analysis}

A statistical analysis was carried out using the SPSS software version 7.1.1. The paired t-test was used to compare the number of live bacteria that penetrated into the radicular dentinal tubules from a surface with and without an intact cemental layer. A p-value of less than or equal to 0.05 was considered statistically significant.

\section{Results}

In the Streptococcus sanguinis group there was significant difference in the number of bacteria that invaded the dentinal tubules without cemental layer (Mean=1072, $\mathrm{SD}=60.23$ ) and with intact cemental layer $(\mathrm{Mean}=244.6, \mathrm{SD}=7.76) ; \mathrm{p}$-value $=0.000($ Table 1$)$ (Table 2).

In the Aggregatibacter actinimycetemcomitans group, there was 
a significant difference in the number of bacteria that invaded the dentinal tubules without cemental layer (Mean=172.4, $\mathrm{SD}=6.5$ ) and with cemental layer $(\mathrm{Mean}=13.6, \mathrm{SD}=3.04)$, $\mathrm{p}$-value $=0.000$.

These results suggest that significantly higher number of bacteria penetrated the radicular dentinal tubules without an intact cemental layer. There were relatively fewer bacteria that invaded the dentinal tubules that had an intact cemental layer.

An intergroup analysis was done to evaluate the number of S.S and A.a that invaded the radicular dentinal tubules without cemental layer. The number of S.s that penetrated in the radicular dentin was significantly higher as compared to A.a.

Table I Tabular form for mean and SD for S.s \& A.a

\begin{tabular}{lll}
\hline Groups & Median & SD \\
\hline la & 1072.4 & 60.23 \\
Ib & 244.6 & 7.76 \\
2a & 172.4 & 6.54 \\
2b & 13.6 & 3.04 \\
\hline
\end{tabular}

Ia, S.s without intact cementum; Ib, S.s with intact cementum; 2a,A.a without intact cementum;

$2 b$, A.a with intact cementum

Table 2 Significant difference in the number of bacteria that invaded the dentinal tubules without cemental layer and with intact cemental layer

\begin{tabular}{|c|c|c|c|c|c|c|c|}
\hline \multirow[t]{2}{*}{ Groups } & \multirow[t]{2}{*}{ Mean } & \multirow[t]{2}{*}{ SD } & \multicolumn{2}{|c|}{$\begin{array}{l}95 \% \text { Confidence } \\
\text { interval of the } \\
\text { difference }\end{array}$} & \multirow[t]{2}{*}{$\mathbf{t}$} & \multirow[t]{2}{*}{ df } & \multirow[t]{2}{*}{ p-value } \\
\hline & & & Lower & Upper & & & \\
\hline \multirow{3}{*}{$\begin{array}{l}1 \mathrm{a} \\
\mathrm{b} \\
2 \mathrm{~b} \\
2 \mathrm{~b} \\
\mathrm{~T} \\
2 \mathrm{a}\end{array}$} & 827.8 & 61.19 & 751.81 & 903.78 & 30.2 & 4 & 0 \\
\hline & 158.8 & 9.49 & 147.01 & 170.59 & 37.4 & 4 & 0 \\
\hline & 900 & 61.95 & 823.07 & 976.92 & 32.5 & 4 & 0 \\
\hline
\end{tabular}

Ia, S.s without intact cementum; Ib, S.s with intact cementum; 2a, A.a without intact cementum

$2 b, A$.a with intact cementum

\section{Discussion}

The results in this study point towards the protective nature of an intact cemental layer. Large numbers of Streptococcus sanguinis penetrated into the dentinal tubules when the tooth surface was devoid of cemental layer. This is in accordance with the findings of Meyron et al. ${ }^{17}$ where they found rapid penetration of Streptococcus sanguinis into exposed dentinal tubules. Fewer number of A.a was observed in the dentinal tubules with and without an intact cemental layer. This is in accordance with Giuliana $\mathrm{G}$ et al., ${ }^{14}$ where they recovered lower levels of gram negative organisms from the radicular dentin.

Siqueira et al. ${ }^{20}$ evaluated in vitro root canal dentinal tubule invasion by selected anaerobic bacteria and the scanning electron microscopy (SEM) results indicated that all bacterial strains tested were able to penetrate into dentinal tubules, but to different extents.

During periodontal disease the cementum surface shows loss of collagen, cross banding, break down of dentogingival fibres and dissolution of mineral component. These features are generally perceived by electron microscopy. ${ }^{21}$
Several studies have described invasion of the cementum of periodontally diseased teeth. ${ }^{13,14,19}$ However, it was not evident from any of these studies if the invaded cementum was intact, healthy, or diseased. Exposed cementum is a thin, often discontinuous layer, ${ }^{22}$ and commonly shows surface defects, e.g., at sites where Sharpey's fibers attach to the cementum matrix. ${ }^{12}$ Exposure of cementum to crevicular fluid, bacterial enzymes, or acidic metabolites may induce physicochemical and structural alterations, such as localized resorptive lacunae or demineralization. ${ }^{12,19}$

Periodontal procedures like scaling and root planning can also cause alterations in the cemental layer. Therefore; it seems likely that bacterial invasion associated with periodontal disease occurs after the cementum has been altered by physiological, bacterial, or environmental factors.

Streptococci express multiple surface protein adhesions ${ }^{23}$ that allow cells to bind to a wide range of substrates found in the oral cavity, including other microbial cells, salivary components, host cells, or extracellular matrix or serum components.. ${ }^{24}$ However, while there are considerable data on the mechanisms involved in the formation and development of dental plaque, ${ }^{25}$ relatively little is known about the mechanisms by which oral bacteria penetrate or invade dentin, and cause pulpitis, root canal infection, periapical and periodontal diseases.

Collagen Type I a major organic component of dentin, is recognized by oral streptococci and when absorbed into hydroxyapatite surfaces, it serves as an adhesion substrate. ${ }^{26}$ The ability of oral streptococci to bind to collagen may facilitate bacterial adhesion to exposed dentin or cementum, and subsequently tissue penetration. The antigen I/II polypeptides, expressed on the surfaces of most indigenous species of oral streptococci, ${ }^{24}$ play a major role in mediating Streptococci to collagen. ${ }^{27}$

A.actinomycetemcomitans is small, nonmotile, gram negative, saccharolytic, capnophilic, round-ended $\operatorname{rod}^{4} A$. actinomycetemcomitans binds to collagen I,II,III and V but not IV. It has the ability to invade host cells, penetrate gingival epithelium and survive within eukaryotic cells. These organisms occur in locations like the epithelium wall, epithelial side of basal lamina, connective tissue and alveolar bone. ${ }^{28}$

Few reports have shown the presence of A. actinomycetemcomitans in periapical lesions as well. A. actinomycetemcomitans is a resident component of the oral microbiota and is commonly found in periodontal infections, but its presence in periapical and root end samples must be considered as one of the causes in persistent endodontic infections. ${ }^{29}$

Although pocket debridement suppresses components of the subgingival microflora associated with periodontitis, ${ }^{30}$ periodontal pathogens may return to baseline levels within days or months. ${ }^{31}$ The return of pathogens to pre-treatment levels generally occurs in approximately 9 to 11 weeks, but can vary dramatically among patients. $^{32}$

Failure to eliminate residual bacteria in the periodontal pockets, root surfaces and dentinal tubules can cause re-colonization of bacteria and reinfection. Various treatment modalities such as systemic and local antibiotics, ${ }^{33,34}$ laser therapy, ${ }^{35,36}$ photodynamic therapy ${ }^{37}$ have been used as adjuncts to non-surgical periodontal therapy to eliminate residual bacteria and have shown promising results in further reducing the bacterial counts. 
High-resolution confocal microscopic images can be made of either the surface of a sample or beneath the surface. With microscopes running under normal conditions, the optical section thickness is $>1 \mu \mathrm{m}$ and the effective penetration into enamel and dentin a maximum of $100 \mu \mathrm{m} .{ }^{38}$ Confocal Laser scanning microscopy was used in this study since it allows us to determine the levels of Live (green) and dead (red) bacteria with the help of the fluorescent dye. Also, optical sections of about $1 \mu \mathrm{m}$ can be obtained. Therefore, appropriate images from the inner sections of the specimen can be recorded. Specimen processing techniques can cause disruption of bacterial cells on the surface of the specimen.

The drawback of this study is that it was performed on extracted teeth using single organisms. Future studies can be done using an $e x$ vivo model where freshly extracted teeth can be analyzed immediately after extraction. Also, various treatment modalities can be assessed wherein pre and post treatment levels of live and dead bacteria can be evaluated.

\section{Conclusion}

An intact cemental layer is an essential barrier for invasion of bacterial species into the dentinal tubules. Presence of bacterial species in the dentinal tubules can cause re-colonization of bacteria in the periodontal pockets, persistence of periapical infections or cause pulpal inflammation.

Therefore, maintaining the integrity of the cemental layer and attempting to regenerate lost cemental tissues through various regenerative procedures should be of prime importance.

\section{Acknowledgements}

None.

\section{Conflict of interest}

The author declares no conflict of interest.

\section{References}

1. Bascones Martínez A, Muñoz Corcuera M, Noronha S, et al. Host defence mechanisms against bacterial aggression in periodontal disease: basic mechanisms. Med Oral Patol Oral Cir Bucal. 2009;14(12):e680-685.

2. Zhang L, Henson BS, Camargo PM, et al. The clinical value of salivary biomarkers for periodontal disease. Periodontol2000. 2009;51(1):2537.

3. Jenkinson HF, Lamont RJ. Streptococcal adhesion and colonization. Crit Rev Oral Biol Med. 1997;8(2):175-200

4. Haffajee AD, Socransky SS. Microbial etiological agents of destructive periodontal diseases. Periodontol2000. 1994;5:78-111.

5. Arakawa S, Nakajima T, Ishikura $\mathrm{H}$, et al. Novel apoptosis inducing activity in Bacteroides forsythus: A comparative study with three serotypes of Actinobacillus actinomycetemcomitans. Infect Immun. 2000;68(8):4611-4615.

6. Tronstad L, Langeland K. Effect of attrition on subjacent dentin and pulp. J Dent Res. 1971;50(1):17-30.

7. Pashley DH. Clinical considerations in microleakage. J Endod. 1990;16(2):70-77.

8. Peters LB, Wesselink PR, Moorer WR. The fate and role of bacteria left in root dentinal tubules. Int Endod J. 1995;28(2):95-99.
9. Love RM. Bacterial penetration of the root canal of intact incisor teeth after a simulated traumatic injury. Endod Dent Traumatol. 1996a;12(6):289-293.

10. Kopczyk R, Conroy C. The attachment of calculus to root planed surfaces. Periodontics. 1968;6(2):78-83.

11. Langeland K, Rodrigues H, Dowden W. Periodontal disease, bacteria and pulpal histopathology. Oral Surg Oral Med Oral Pathol. 1974;37(2):257-270.

12. Adriaens PA, Edwards CA, De Boever JA, et al. Ultrastructural observations on bacterial invasion in cementum and radicular dentin of periodontally diseased human teeth. J Periodontol. 1979b;59(8):493-503.

13. Adriaens PA, De Boever JA, Loesche WJ. Bacterial invasion in root cementum and radicular dentin of periodontally diseased teeth in humans. J Periodontol.1987a;59(4):222-230.

14. Giuliana G, Ammatuna P, Pizzo G, et al. Occurrence of invading bacteria in radicular dentin pfperiodontally diseased teeth: microbiological findings. J Clin Periodontol. 1997;24(7):478-485.

15. Michelich VJ, Schuster GS, Pashley DH. Bacterial penetration of human dentin in vitro. J Dent Res. 1980;59(8):1398-1403.

16. Meryon SD, Jakeman KJ, Browne RM. Penetration in vitro of human and ferret dentine by three bacterial species in relation to their potential role in pulpal inflammation. Int Endod J. 1986;1(5):213-220.

17. Meryon SD, Brook AM. Penetration of dentine by three oral bacteria in vitro and their associated cytotoxicity. Int Endod J. 1990;23(4):196-202.

18. Al-Nazhan S, Al-Sulaiman A, Al-Rasheed F, et al. Microorganism penetration in dentinal tubules of instrumented and retreated root canal walls. In vitron SEM study. Restor Dent Endod. 2014;39(4):258-264.

19. Daly CG, Kieser JB, Corbet EF. Histological assessment of periodontally involved cementum. J Clin Periodontol. 1982;9(3):266-274.

20. Siqueira JF, De Uzeda M, Fonseca MEF. A scanning electron microscopic evaluation of in vitro dentinal tubules penetration by selected anaerobic bacteria. J Endod. 1996;22(6):308-310.

21. Bosshardt DD, Selvig KA. Dental cementum: the dynamic tissue covering of the root. Periodontology 2000. 1997;13:41-75.

22. Moskow B. Calculus attachment in cemental separations. J Periodontol. 1969;40(3):125-130.

23. Hasty DL, Ofek I, Courtney HS, et al. Multiple adhesins of streptococci. Infect Immun. 1992;60(6):2147-2152.

24. Jenkinson HF, Demuth DR. Structure, function and immunogenicity of streptococcal antigen I/II polypeptides. Mol Microbiol. 1997;23(2):183190.

25. Kolenbrander PE. Oral microbial communities: biofilms, interactions, and genetic systems. Annu Rev Microbiol. 2000;54:413-437.

26. Liu T, Gibbons RJ. Binding of streptococci of the mutans group to type 1 collagen associated with apatitic surfaces. Oral Microbiol Immunol. 1990;5(3):131-136.

27. Love RM, McMillan MD, Jenkinson HF. Invasion of dentinal tubules by oral streptococci is associated with collagen recognition mediated by the antigen I/II family of polypeptides. Infect Immun. 1997;65(12):51575164 .

28. Raja M, Ummer F, Dhivakar CP. Aggregatibacter Actinomycetemcomitans- a tooth killer. J Clin Diagn Res. 2014;8(8):ZE13-ZE16.

29. Pereira RS, Rodrigues VAA, Furtado WT, et al. Microbial analysis of root canal and periradicular lesion associated to teeth with endodontic failure. Anaerobe. 2017;48:12-18. 
30. Slots J. Subgingival moicroflora in periodontal disease. J Clin Periodontol. 1979;6(5):351-382.

31. Magnusson I, Lindhe J, Yoneyama T, et al. Recolonization of a subgingival microbiota following scaling in deep pockets. $J$ Clin Periodontol. 1984;11(3):193-207.

32. Greenstein G. Periodontal response to mechanical non-surgical therapy: A review. J Periodontol. 1992;63(2):118-130.

33. Bernimoulin P, Purucker H, Mertes B, et al. Local versus systemic adjunctive antibiotic therapy in RPP patients. J Dent Res. 1995;74:481.

34. Mombelli A, Lehmann B, Tonetti M, et al. Clinical response to local delivery of tetracycline in relation to overall and local periodontal conditions. J Clin Periodontol. 1997;24(7):470-477.
35. Gokhale SR, Padhye AM, Byakod G, et al. A comparative evaluation of the efficacy of diode laser as an adjunct to mechanical debridement versus conventional mechanical debridement in periodontal flap surgery: a clinical and microbiological study. Photomed Laser Surg. 2012;30(10):598-603.

36. Moritz A, Schoop U, Goharkhay K, et al. Treatment of periodontal pockets with a diode laser. Lasers Surg Med. 1998;22(5):302-311.

37. Atieh MA. Photodynamic therapy as an adjunctive treatment for chronic periodontitis: a meta-analysis. Lasers Med Sci. 2010;25(4):605-613.

38. Watson TF. Fact and artefact in confocal microscopy. Adv Dent Res. 1997;1(4):433-441. 